\title{
Relationship between Ottoman and Albanian Culture as an Intercultural Example of Interaction
}

\author{
Osman Özkul* and Nazim Zullufi** \\ *Departman of Sociology, Faculty of Science and Literature, Sakarya University, Sakarya, Turkey. \\ **An researcher sociologist, Pristina, Kosovo.
}

\begin{abstract}
Islam and Ottoman cultures have had a significant impact on the Albanian culture from the 15th century to the present. Islam has also been a shield that protects Albanian culture from Slavic and Greek assimilations. Therefore, the Islamic culture has had a very strong influence on the components that formed Albanians' social structure. It is possible to see the effects of Islamic culture on Albanians' life styles, family cultures, death and marriage rituals, economic lives, legal relations and all mentality structures and the system of values that constitute the society. It was not difficult to adapt to the Albanian culture especially for the Ottoman interpretation of Islam because these two cultures have been built similarly on the old Mediterranean cultural basin. It is possible to find many common values between the two cultures. For example, the values including tolerance, indulgence, freedom, and, most importantly, being against discrimination are the elements that made these two cultures closer and united to each other. It is sufficient to look at the history in order to understand how tolerant Albanians are about religion. They have been able to live together with three different religions in high tolerance for centuries. The level of tolerance is such that there are individuals of different religions in a tribe or even in a family. The Islamized Albanians can also maintain their traditions, customs and authentic lifestyles along with the Islamic culture.
\end{abstract}

Key words: Cultural Relationship, Islam, Ottoman, Albanian, Culture, Tolerance.

\section{Introduction}

This article aims to set forth the effects of Islam and its culture on Albanian culture. In order to achieve this aim, the study tries to find the answers to the following questions: How did the first contact of Islamized Albanians with the Islam take place? So, how did Albanians become Muslims? What are the effects of Islam on Albanian culture? How did the Islam and its culture affect Albanian society institutionally? With these questions, the answers of two more specific questions have been tried to be found. First, why the majority of Albanians who had adopted Christianity for centuries abandoned it and adopted Islam with the Ottoman domination in the $15^{\text {th }}$ and $16^{\text {th }}$ centuries? The second question is how can the relationship that Albanians established between their national and religious identities be explained?

Considering that there is a mutual relationship between religion and culture, it can also be assumed that there are some common or similar elements between Islam and Albanian culture. Based on this assumption, the similarities between the Kanun of Leke Dukagjini (2011), which Albanians considered as a kind of constitution throughout their history, and some basic elements of Islam, can be accepted as the starting point. These similarities and the richness that Islam has as a requirement of its universality as well as the tolerant attitudes of Albanians towards their religion may have played a facilitating role in cultural interaction, too.

Durkheim explains in detail in his book The Primitive Forms of Religious Life (Durkheim 2005, 67) that religion has an a priori understanding and a central position in social life. Also T. S. Eliot included the relationship between religion and culture in his book Notes towards the Definition of Culture (Eliot 1987, 19). According to him, religion is an important source that nurtures the culture. Culture is the embodiment of 
a society. Moreover, according to him a culture or even a civilization can develop and emerge depending on just one religion.

From this perspective, religion has a very important function in all societies. Culturally, although societies were differentiated and changed, they have religious characteristics in certain forms. On the other hand, religious culture as a holy phenomenon has an autonomous mechanism, which operates to a certain extent entirely outside the structure of society, as it usually has an integrated aspect with the social structure (Günay 2010, 415). Ziya Gökalp, mentions about this phenomenon when he describes different qualities of the Turkish nation from other nations in his book, the Principles of Turkism (Gökalp 2005). While explaining the most important factors that determine the culture and identity of a nation, Gökalp also emphasizes the importance of religion together with elements such as history, language, and morality.

This phenomenon is also important for Balkan societies that had been under the influence of different civilizations throughout history and still have very different cultural colors. Aliya Izzetbegovic, who is an analyst made an analytical research on the cultural history of the Balkans, describes this region as a meeting point of the East and the West; or the bridge of culture, civilization and ideological ideas (Izzetbegovic 2015). It can be expected that researching the cultural structures of the ethnic groups in this geography would make a contribution to the solution of some cultural and social problems.

For this purpose, researches that will contribute to the political, social, and cultural peace of the Balkan societies are needed. In this study, which examines the relationship between Islam and Albanian culture, a method of internal comprehension was followed by using mainly Albanian sources. Ethnological and anthropological studies of mostly the Albanian cultural historians were referred, while the answer to the question of how Albanians have been influenced from Islam has been researched. As a Turkish source, the master's thesis (Rruga 2011) that was prepared by Rruga, who is another Albanian, was used. However, in this thesis, the history of the relationship between Albanian people with Christianity and Islam was explained, but cultural relations were not given an important place. In order to reach the objectives stated in the article; some historical and cultural data and the discussions in the Albanian literature have been tried to be compared.

In the article, the ethnic and religious history of Albanians was discussed. In this context, the common and different qualities with other societies in the Balkans have been mentioned. Then, it was examined that how Albanians were introduced to Islam. Following this, the process of Islamization in the Ottoman period was explained based on some quantitative data. After this section, relations and similarities between Albanian identity and cultural elements and Islam and its culture were examined comparatively in the light of the historical data.

\section{Pre-history of Albanians and Introduction to Islam}

The ethnic origins of Albanians were rooted in Pelasgians, who are known as one of the oldest tribes in Europe. In the same way, the Greeks also have their roots in Pelasgians. Many historians believe that Illyrians (Illyria) and Pelasgians are relatives with the Dorians that was one of the Hellenistic tribes and were the founders of the Hellenistic culture. According to European historians, Albanians are descended from the ancient Illyrians. These are among the oldest tribes living in the Balkans together with Slavs and Greeks. Again, some historians cannot give exact information on this subject, some of them refer to Illyrians, and another part accepts the Etruscans as their ancestors. However, the idea that Albanians came from Illyrians have gained weight (Durham 1909, 19).

Albanians, who were introduced to Islam long before the arrival of the Ottoman Empire, emphasize that they are one of the oldest people in Europe, only Balkan nation that does not base their national identity on religious differences, and especially the most of them are Muslims (Veliu 2006, 48). The first inviters of Islam went to Sicily during the period of Andalusia and then to Albania. It is claimed that besides the inviters of Islam the Muslim traders who came for trading were effective in the conversion of the Albanians to Islam. Arab traders, who came to Europe, so the Adriatic, through Ionian and Mediterranean seas and different trade routes, have contributed to the spread of Islam in Albanian territory by using trade routes (Veliu 2006, 45).

An unusual claim about this subject is found in the Menakıpname of Kethüda zade Mehmet Efendi who was among the ulama in the Ottoman Empire. According to him, the origin of the Albanians is explained by the settlement of a Muslim community who migrated from Arabia in the 8th century (Emin Afendi 1294, 54). According to an unaccredited view supporting this claim, Arab-Islamic culture was seen in the tribes living 
on the shores of the Adriatic Sea in the $8^{\text {th }}$ century. These contacts were for commercial, military and political purposes, and the inviters were those who lived a nomadic life and even their effects were intermittent, they were seen until the $11^{\text {th }}$ century. It is also accepted that this effect lasted until 1023 (Basha 2000, 35).

In fact, Veliu defends that Islam has been adopted in Gora, Rahovec, some villages in Prizren and in some parts of Suhareka a century before the arrival of the Ottomans. However, Alexander Popovic opposes this claim which is about the Albanian's introduction of Islam, and says that "we do not see any traces of Islam in Albanian territory by the end of the $14^{\text {th }}$ century and before the first half of the $15^{\text {th }}$ century" (Rruga 2011, 49).

Another historian describes the reason why Albanians accepted Islam as a reaction to the pressure of Serbs. Albanians remained under the persecution of the Serbian church and those who were not subject to the Serbian Church or those who did not accept it were being killed by the sword; their goods and everything else were seized by the church. This kind of persecutions enraged Albanians against the church. When the Ottomans arrived, the local people accepted the religion of Islam against these atrocities and adopted Islam easily.

\section{Albanians in the Ottoman Empire Period}

As mentioned above, it is possible to see the traces of Islam in the Balkans before the Ottoman Empire arrived to these lands. However, the spread of Islam took place institutionally only with the arrival of the Ottomans into the Albanian lands at the end of the $14^{\text {th }}$ century (Kiel 1990, 67). Karl Topia, who led the Toska region during the reign of Sultan Murat I in 1385, asked the Ottomans to help him to fight against Balsha who ruled the Geg region. Thus, the Ottomans made political and military contact with the Albanians by meeting with them for the first time. After these contacts, many Albanian rulers recognized the vassalage of Sultan Murat I. These events led to the spread of the Islam through the Albanian territory. Thus, Albanians accepted Islam without being exposed to any pressure or oppression by the Ottoman soldiers.

According to some Christian missionaries who are against this thesis, the Ottomans resorted to oppressive and violence policies on Albanians for their conversion to Islam. Conversion of Albanians to Islam was the result of these pressures. However, there is no example that the Ottomans imposed Islam to a society by oppression. According to Islam, even such oppression is prohibited. The verse that "There is no compulsion in religion..." (Koran 2003, 2:256) was considered as an open order in the Ottomans.

Despite the successes that had been achieved during the $16^{\text {th }}$ century, Islam has not yet spread widely among the Albanian population. The first steps of Islamization process of the rural population had been taken with the fact that the feudal layer became Islamized and entered into the Ottoman rule and a significant part of the city population was oriented towards Islam. While the Islamization of the rural population was at the level of $1.7 \%$ in the first quarter of the $16^{\text {th }}$ century, Albanians' conversion process and dynamics on Islam have increased since the second half of the century (Duka 1991, 69).

By the end of the $17^{\text {th }}$ century, the majority of the population in places dominated by the current Albanian population accepted Islam. For example, according to the Roman Catholic Diocese of Tivar, there were only 2000 Catholics in 1624. At the end of the $17^{\text {th }}$ century, their church in Tivar was in such a situation that it was not being used for religious services because only two Catholic families were living in the city (Pirraku 1993, 67).

Since the beginning of the $18^{\text {th }}$ century, the $3 / 4$ of the population that were in the regions where the Albanians were living, was Islamized. Again, according to these historical sources, Islam had an important role in the protection of Albanian national identity.

Thanks to this, Albanians have raised many scientists, educators, diplomats, state government administrators, politicians, and commanders (Kiel 1990, 78).

It is understood that the adoption of Islam by the population in Albanian cities took place in two ways depending on the socio-economic dynamics. The first one is that the urban residents voluntarily adopted Islam by the influence of socio-economic factors. The second is through the slowly Islamization of artisans who came to the city from the countryside. Just because the local urban population was not capable of meeting the needs of the expanding urban economy, some of the artisans in rural areas had the opportunity to settle in the city. Thus, those who came to the city from the rural, was able to enter the city by doing so. Therefore, the fact that artisans came to cities from rural areas was considered as a convenient way for the urban population to accept Islam. 
Some examples that support this view can be found in the cities of Berat and Elbasan. In 1583, there were 185 artisans who came from the villages such as Fratar, Tojar, Gekâr, Dobronik and Gerbes. Elbasan had 39 artisans in this category in the same year. The fact that some of the artisans, who came to the city of Berat, had the Christian surname and another part of them was recorded in the book with the surname Abdullah, which indicates that this part of the urban population became Muslim newly (Kiel 1990, 82).

Another issue that is required to be emphasized on the subject that the majority of Muslim communities in various cities recorded in the Ottoman registries are composed of artisans. Therefore, some of the population, who were engaged in production and service, began to convert to Islam. In 1583, the number of Muslims increased rapidly in cities such as Berat, Gjirokastra, Shkodra, Ipek (Peya), Prizren, Pristina, Vuchitern (Pirraku 1993, 53). This means that the reorganization of the production activities by the Ottoman administration there also affected the process of Islamization in the cities. Of course, the fact that material production was based on Islamic principles led to changes in the structure of the urban population. Since the spread of Islam among the urban population developed gradually, it is useful to explain some important issues affecting this phenomenon.

The differences between the cities of Kosovo and other Albanian regions in terms of the start dates of Islamization and the pace of development of this process are, above all, related to a certain situation that Kosovo experienced during the occupation of the Ottomans. As it is known, the Kosovo region had been under the rule of the Serbian administration and the Serbian Orthodox Church for many years. The settlement of the Ottoman sovereignty in the region in question led to the collapse of the Serbian feudal class and weakening of the dominant position of the Serbian Orthodox church (Pirraku 1993, 54).

As a result of the new conditions created by the settlement of Ottoman domination in Kosovo, the Albanian population in the region gradually abandoned the Orthodox religion and converted into Islam. The main reason for this was that the Orthodoxy, which rested upon the administration of the Serbian church in this region, lost its influence among the Albanians, since it served the Serbian feudal class and the dominance of the Serbian State which were stranger to the Albanians. As a result of these conditions, Kosovo has made significant progress in the Islamization of the urban population (Rizaj 1982, 45). In response to the differences in terms of time and space, the Islamization graphic of the urban population in the Albanian regions in the $16^{\text {th }}$ century has shown a steady increase, and at the end of this century, most of the population mentioned converted to Islam.

It is understood from this historical information that the dimensions of this development, which took place during the $17^{\text {th }}$ and $18^{\text {th }}$ centuries in various regions of Albania about the adoption of Islam, show a very concrete and real appearance. Nevertheless, there is no doubt that the information is insufficient for giving the exact stage that the Islamization of the population in all the Albanian territory at the end of this period reached. On the other hand, if we consider the religious structures of Albanians, it is understood that the majority of the Albanian population accepted Islam in the $18^{\text {th }}$ century based on the same data.

\section{The Effects of Ottoman Culture on Institutional Structure}

It was not difficult for Albanians, who were known for their religious tolerance, to coexist with the tolerant Islamic religion. Some specific cultural values of the Albanians (respect for women, older people, children and, hospitality, keeping their promises, etc.) and the elements of Islam were compatible with each other. For this reason, Islam has made a significant contribution to the preservation of these values, thus it assumed the role of an umbrella for Albanian identity.

The family subject is a good example for this. After the adoption of Islam in Albanian lands, the polygamy was not adopted among Albanians. Monogamy was common in the Albanian family and remained so with some exceptions. This structure could be sustained in Albanians as well as in the whole Balkans thanks to the tolerant attitude of Islam to allow for cultural pluralism. There was no endogamy in Albanians; people were not allowed to marry even if they are from same tribe. In this way, the customs of traditional marriage in the family has been preserved (Elsie 2011, 37).

With these basic elements of the Albanian family, especially the sexual relations and the marriage institutions, were sustained; The traditional fraternity, kinship, and tribal structure, which played an important role in protecting the ethnic roots of Albanians, were also preserved. The family, which has such a social structure, has provided the Albanians who have different religions to live together peacefully. There were even marriages between people of different religions. 
According to the statements of Ahmet Cevdet Pasha, who explained his observations while he was working as an inspector at the Shkodra, there were examples of some marriages between Catholic Albanians and Muslim Albanian families. Cevdet Pasha gives the following information when he talks about the need for good treatment for the reconciliation between the Christians in the Shkodra Mountains and the followers of Islam:

"When we mentioned about the reconciliation of Islam and Christians; most of Christians in the Shkodra were Latin (Catholic), and the unity of the followers of Islam and Latins in their minds are unprecedented. They salute each other. In the battles, the Latins are subject to Muslim flag-bearer and likewise the Muslims to the Latin flag-bearer, they act in a complete unity. They respect each other's deaths by treating them as martyrs. Even Latins, when they will marry another woman besides the woman who they were already married, they need an imam to perform the marriage ceremony. ... After the priest had performed the marriage ceremony of Latins in the Shkodra, husband and wife were taken to the court, have their marriage approved by the Kadi (Islamic judge), and pay five kurus of fee. But the Orthodox were satisfied with the marriage ceremony of the priest and they were not going to the Kadi (Islamic judge)" (Cevdet Paşa 1991, 183-84).

Another element that continues without a major change in Albanians is the understanding of law based on customs and traditions. It can be said that the Albanians did not acquire too many components from the Islamic law by adhering to the abovementioned laws. Another reason for this may be that many custom rules are already compatible with the Islam. This issue will be discussed broadly in the following section.

\section{Relation between Ottoman and the Albanian Identity}

In this respect, it is seen that there is a dialogical relationship between Islam and Albanian identity. On the one hand, it is possible to mention about an identity that is independent from religion, while there has been seen a nation identified with religion in other respects.

According to İsmail Kemal (1920), who supported this point of view, Albanians have been representing a pure and unspotted national identity, despite the conquests of Romans, Byzantines, Normans, Bulgarians, Serbs, Italians and Turks for centuries. Their honor, family and country are the values that they will die for without hesitation since the ancient times (Sayg11 2014, 37).

Smith's thesis can be given as an example of a relatively conciliatory approach against this radical Albanian nationalist approach. A.Smith, who is one of the contemporary identity researchers, adheres to the Albanian ethnic identity thesis, but aims to challenge the modern view of Albanian nationalism. According to him, the majority of Albanians against the Ottoman Society were a group that categorized themselves differently, but were also relatively compatible with them. Albanians should be seen as people who protect their common ethnic origin but also share their culture (Smith 1999, 12-13).

On the other hand, despite these negative perspectives, there are also approaches that assume an important relationship between Islam and Albanian identity. The similarity of some rules, which were adopted and adhered by Albanians in their social relations since Middle Ages, with the rules of Islam may give a clue about this. For example, Dukakin laws from the $15^{\text {th }}$ century among Albanians were respected to protect the social order. These traditional laws order punishment for the robber proportioned to what was stolen, killing the relatives of the murderer as a "tit for tat" for the punishment of murder. These methods of punishment are like those in the Islamic law such as cutting the hand of the robber and retaliation punishments.

According to another approach that supports this relationship, Islam has played a fundamental role for the formation of Albanian identity. Although they felt themselves as Albanians, they could not stay as Albanian without being Muslim. It was not easy to separate themselves from Muslim Turks. Islam and the Turks made a significant contribution to the preservation of the national identity of Muslim Albanians (Lomonosov 2013, 11).

Since Albanians are a tolerant nation and Islam is a tolerant religion, Islam has been the most important determinant of Albanian nation's consciousness because the values of tolerance, equality and humanity are also the result of divine knowledge. H. İbrahim Dalliu, a researcher and a commentator who lived in the 1930s thinks about the relations between religions in Albanians that all the Albanians are brothers no matter what religion they believe, they will always live together and they will sacrifice their lives for their homeland. Acting with the same consciousness, Ilo Mitko Qafzezi, who decided to translate the Qur'an into Albanian in the 18th century, says that the reason of this translation was to make Christian Albanians and 
the Muslim Albanians understand the differences between them by understanding this sacred book (Hamiti 2009, 37).

The result that we derive is that the Islamic religion saved the national existence of Albanians from the Slavic-Orthodox assimilation. Thus, the national consciousness of the Albanian people was nurtured in a manner consistent with their cultural dynamics. The Albanians are the nation that has three different religions and they have lived in peace by respecting the characteristics and doctrines of these religions, thus the Albanian nation has been formed.

Although the Albanians maintained their identity, culture, and language after Islamization, Islam has affected many important elements of life because they have lived under the domination of the Ottoman Empire for hundreds of years. Moreover, the Albanians were promoted to important political positions during these years. In this way, the people also adopted Islam and then began to practice this religion by internalizing it in all areas.

Although most of the Albanians have adopted the religion of Islam, they have developed their lives according to their authentic customs and ethno-cultural understanding by preserving their cultural characteristics and national identity at the same time. These beliefs provide information on the economic and cultural level, psychology, mentality and life style of the Albanians (Selimi 2009, 39).

Thus, the Albanian identity was tried to protect by identifying strong Islamic culture and national cultural features. Throughout the Ottoman rule, family life and traditions were undoubtedly preserved generally as the precious treasure of a great cultural heritage with their authentic features. The Ottoman religious ceremonies and the advanced and rich culture that had existed among Albanians for centuries lived together by exchanging with each other (Sulejmani and Martesa 1988, 78).

However, it cannot be said that this effect is the same in all regions. For example, the impact rate is greater in some parts of Western Macedonia and Kosovo where Islamic consciousness is stronger. One of the most important reasons for this is that Albanians often used Islam as a shield to resist against the threat of Slavization. This is an expression of resistance for the preservation of ethnic and religious culture and survival in Albanian territory. These effects will be examined in more detail in the following subsections.

\section{Interaction between Ottoman and Albanian Culture}

It is understood that there is a unique relationship between Islam and Albanian identity and culture according to the information obtained from historical and anthropological sources. It is possible to explain this relationship by citing the concept of cultural dialogy (Morin 1988) used by contemporary French philosopher Edgar Morin to explain European culture. In the following subsections, examples of architecture, language, literature, daily life, and family life, which demonstrate this relationship in Albanian culture, will be examined.

\subsection{Effects of Ottoman on Albanian Architecture}

Architecture was one of the first Islamic elements to be seen in the Albanian lands; by the construction of mosque, lodge, mausoleum, bath, palace, bridge etc. Some Albanian architects were effective in preserving the local spirit and culture, in mosques and other traditional artefacts. The best evidence of this is the Stone Mosque in Prishtina, the Vushtrri Bath and so on. Albanian researchers are of the opinion that mostly the traditional elements exist in Ottoman Islamic Architecture in Kosovo, thus it was different from other examples of Ottoman architecture, and Kosovo is the Albanian heritage.

For example, Fejaz Drancholli in his book Rrënimi i Kullës Shqiptare states that despite the strong influence of the Ottoman Empire, traditional Albanian architectural elements prevailed in Islamic architecture in Kosovo. The thesis of Drancholli is that this architecture has its own style and originality (Drançolli 2004, 35). According to him, the Islamic architecture of Kosovo, which developed during the Ottoman period, was special and constitutes the Albanian-Islamic style of architecture. Such examples are available in the entire Albanian cultural basin.

\subsection{The Effects of Ottoman on the Albanian Language}

Albanians maintained the Albanian language and developed it with all its originality better than Catholic and Orthodox Albanians, which were two powerful groups in the regions where Albanians adopted Islam. In Kosovo, Montenegro, and Macedonia, where Islam was not adopted, they were all Slavized, while they were Greekized in the Southern Epirus. However, the Muslim Albanians also had the opportunity to maintain 
their identity thanks to the connection they established with the terms which were the conveyor of the Islamic culture of the Ottomans. Today, the influence of this phenomenon is observed among Albanians and other Muslim elements in the Balkan region.

In Muslim Albanians, terms such as Allah, prophet, angels, book, prayer, charity, sharia, faith, imam, pilgrim, salavat, mercy, worship, heaven, hell, mudarris, muezzin, and yasin were added to the language by being subjected to Albanian phonetics and morphology in most cases. But the Albanian-originated words, which are synonyms of the ones mentioned above, such as Zot, profet, engjull, falje, miresi, besim, kanun, ferr, parajs have also been preserved and are still being used. The terms and words borrowed from Islam, such as the Mosque, lodge, tomb, palace, bath, mihrab, minaret, sermon, and repentance, estağfurullah, nauzubilillah and similar words like regret and swear... The names such as Abdullah, Muhamet, Ramadan, İsmail, Hasan, Hüseyin, Rahim, Mehmet, Ahmet, Rustem, Bayram, Fatime, Hatice, Miradiye, Sadiye, Halide and so on have been realized by adapting to the Albanian structure by means of contraction or fonomorphological change. For example: Such as Lah, Met, Ram, Dan, İs, Tsan, Tsen, Rust, Bayr, Fat, Hat, Lid and so on... (Memishi 2011, 49) Thus, the words that entered Albanian have not made a negative effect on the basic structure of Albanian and have not harmed it, but have strengthened it. In this way, the Albanian language has further richened and developed.

\subsection{Albanian Literature, Ottoman and Folklore}

When the Ottoman Empire took over the Albanian lands, then, it came together with a new culture. There are a lot of Albanian men of letters who are writing pieces in Arabic and Turkish. Suzi of Prizren, Meishi of Prishtina, Dukaginzade Yahya Bey in Turkish Literature (Yahya Bey Dukagjini who is known as Yahya of Taşlica, (1496-1582)), and Ahmed Bey Dukagjini, known as Dukaginzade Ahmed Bey in Turkish Literature, are the most famous of them.

Ayazi, Lutfi Pasha and Kochi Bey, who created pieces at the beginning of the $16^{\text {th }}$ century, are also Albanian- origin prose writers (Memishi 2011, 51). These writers made their marks in the Ottoman-Turkish literature, created original works and they opened new ways. Gibi who is the historian of Ottoman-Turkish poetry, emphasizes that by saying that "They added originality to the Ottoman-Turkish literature because they were Albanian" (Elsie 2011, 82). In this period, an attribution and an act such as writing in Albaninan language in culture, education and religion were common. However, the examples of that the Albanian language began to be written with different alphabets are seen in this period. Muç Gega, Muç Zade, Nezim Frakula, Süleyman Naibi, Hasan Züko Kamberi, Zeynel Bastari, Muhamed Küçük, İpekli Molla Derviş, Tahir Efendi Boşnak, Dalip Fraşeri, Şahin Bey Fraşeri, H. Ali Ulçinaku, Rece Voka, Şehy Maliçi and others (Elsie 2011, 124).

The influence of Islam is not seen much in fairy tales, fables, proverbs, and jokes. However, the prevalence of lyric folk songs is very high, especially in cities and in Sufi orders. The hymn, eulogy, mawlid etc., which are sung firstly in in lodges and then in the family ceremonies, are known. Many heroic songs that are sung for Ali and his sons Imam Hasan and Imam Hussein, and other Islamic elders who are members of an Islamic order draw attention. There are two types of songs preserved and maintained until today. The first genre is the songs known as the old city songs that are sung also today in Central Albania and Kosovo's Elbasan, Tirana and Yakova etc. cities. The second genre is Southern songs composed of rhythm and rhyme with few words that have not preserved their melody and lyrics. Most of these songs are performed without any instrument, only with special rituals accompanied by head and body movements (Memishi 2011, 58).

Despite all of these effects, Albanian literature and folklore preserved their authentic and original spirit while the effects and interactions did not assimilate the Albanian folklore spirit. If we mention about worship, there is very little effect. More precisely, it is almost none except the ritual sections in the Islamic orders and the prayers in Sunnites. It can only be said that the church was replaced by mosque (Memishi 2011, 63).

It is seen that Albanians maintained many traditions from family organization to the minor rituals. For example, mythological elements such as fairy tales, legends, heroic folk songs, ballads, belief in leopard snake, zana and dragon are still preserved. With their positive characters, these elements differ from the characters in the mythology of other Balkan nations; because in other nationalities, zana and dragon are the equivalent of each other, or the serpent that brings evil. Also, they preserved their traditional feasts and bairams such as summer day, harvest day, hidırellez, şmarku and şmitri. Summer day, changed its name to ballokum days in Elbasan and Central Albania and acquired Islamic characteristics (Pulaha 2011, 48). 
In general, Albanians have been maintaining some of their customs even after they adopted Islam thanks to Islam's tolerance and respect that it shows for non-harmful cultural differences. Today, Albanian people continue to visit the tombs and the tombs of the dervishes, tell fortune, and write amulets.

\subsection{Ottoman, Nutrition, Clothing and Housing Culture}

The first and most powerful influence of Islam in Islamized Albanians is about nutrition. The first example of this is related to the prohibition of Islam on pork and alcohol. The second example is the introduction of sweets such as halva on religious bairams and important days. Islam has spread the use of sweets and halal drinks in the kitchen among Albanians upon the prohibition of alcohol. Thus, wine and raki were replaced with syrup and various teas. However, pastry, bagel, dessert, revani etc. were taken from the Ottoman together with their original names. The way meals were served along with their kinds was replaced with oriental table. It is thought that eating the food in a common bowl as an old Ilir-Albanian tradition at the same time.

In many parts of Albanian regions felt, reef, tirqi, xhurdi, artistic socks, sandals; pinked headdresses, vest, shirt, woman apron, xhublet etc. have been preserved in women. But shintiyan, fez, dolman introduced in the cities eventually. The white felt has been replaced with a black taqiyah in some parts of Macedonia, in the Morova Valley and in Muzeçe (generally in Orthodox). Drita-Halimi Statovci, in her book named Albanian Clothing in Kosovo, discusses that Albanian clothing has been protected in Albanian territory, especially in Kosovo, and there are very few elements added to this clothing type. In this book, after the registration of a large part of the original Albanian clothing preserved in Kosovo, she shows two or three elements of Eastern dresses, and especially ferace as the signifier of Islam:

"Apart from these old Ilir-Albanian originated and typical folk dresses, clothes that are named as shintiyan in Kosovo were also worn. For example, ferace can be given as an example of Islamic influence, or more precisely the woman's covering her face and body when she goes outside. What is characteristic is that both the Muslims and the Christians wear shintiyan... The effects in men's clothing are mostly seen in the urban population of Muslim and Christian feudal aristocracy. The masses of the people, or more precisely the peasants, have always resisted the oriental influence. Therefore, there are very few examples of wearing oriental clothes in villages. Only men wear fez and a kind of trousers, which are made up of red or dark blue baize and sewn with the oriental style as in all Balkans" (Statovci 2009).

According to Mark Krasniqi in his book Gjurme e Gjurmime; Albanians have entirely protected their housing type, both their tower type houses and their traditional houses upon certain regions. In the same way, they have also preserved the way of enclosing the courtyard with fence. While there were few courtyard walls in Rugova, Golak, Shala etc. the courtyards in the flat places and cities are enclosed with stone, lath (Krasniqi 1979, 47).

The main change is adding the bathroom and Turkish baths into the house and into the room. Despite the prevalence of this custom, there is no separation between men and women within the house. Separate rooms have never been used in the regions such as Rogova, Has, Opoya. Leskovça / Serbian immigrants introduced the separate room in the regions of Golak, Lap, Karadak and Bajgora Şalas1, after the year 1878. Over time, the room has become the Albanian Institution with the characteristics of education, national, political, military etc. by playing a major role in the Albanian thought and organization,

\subsection{The Relations of Ottoman with Birth, Death and Marriage Customs}

It cannot be said that Islam has a great effect on the birth rituals, except giving Muslim names that are adapted to the structure of the Albanian language and are abandoning to be baptized in the church naturally. Nevertheless, in some regions, birth rituals were a mixture of pagan and Christian customs. Yllka Selimi, thinks that the rituals of Islam affected the customs of women who do not become pregnant easily, especially regarding the Macedonian Albanians. According to him, woman who give birth early, in fact, in the sixth or eighth month, and whose baby dies, goes out on for three Fridays and counts nine people from the community who are going to make the Friday prayer for that the child to be born on the ninth month (Sulejmani and Martesa 1988, 80).

Marriage traditions generally preserved their traditional characteristics in most of Albanian regions. The only change is that the wedding ceremony is performed by the imam at home before the groom enter the bridal chamber, not in the church (Sulejmani and Martesa 1988, 82). Albanians practiced the tradition of 
bride price (mehir), a kind of financial guarantee that is committed to women, in the case of death or divorce in very few regions, generally in some parts of Macedonia and in some cities. Although the Islamic religion permits polygamy, it is seen very rare. The Albanians also preserved the rule of not marrying with relatives strictly; marriages even within the same tribe are prohibited. They have always protected the father's side family vessel. The same situation happened also with the protection of marriage feasts and traditions. Old Albanian traditions have mostly been preserved in asking for the girls hand in marriage, betrothal and other marriage rituals (Xhemaj 2005, 53).

Only some minor elements from Islam have been added to these rituals. These are described by Uke Xhemaj in the Wedding at the Dukagin Plain chapter of the Book of Cultural Layers:

"We see exogamy with the -marriage out of the tribe- and punching the groom while he is entering the bridal chamber and etc. in terms of social layers such as survival of economic-social formations and social organization. The second group layers belong to the common life of religious rules. This means the first bed with a common layer with Christian and Islamic elements. We assume the ritual of the bread which is eaten from the first table called the hodja table as the part of this layer. Moreover, with imam's wishes of a blessed marriage, with the Quran and prayer reading (in the Muslim Albanians), the groom is punched from his back by his friends, besides his entering into the nuptial chamber" (Xhemaj 2005, 54).

According to the information obtained from the literature of Albanians, as with many other cultural elements, the rules adopted by the influence of the Islam and the authentic marriage customs of Albanians have been continuing to live together. In this respect, it is concluded that the Albanian cultural elements after they became Muslim and their old authentic characteristics have been harmonized and protected by a tolerant approach.

\section{Conclusion}

The first encounter of the Albanians with the Islam was earlier than the arrival of the Ottoman Empire. But the intensified Muslimization of Albanians took place during the Ottoman period and in a certain period. First, it started from the upper levels of social status and then covered all regions by including a wider environment. There are many factors that contribute to the Islamization of Albanians such as political, economic, military, religious, social, cultural, ethnic, and ethical.

Islam became part of their lives by influencing Albanian culture and traditions. Albanians' mentalities and views are mostly affected culturally and economically. But there has never been any pressure on the values and original characteristics of Albanians. For this reason, Islamized Albanians have maintained their culture, language, literature, and lifestyles thanks to Islam.

The polygamy, which is allowed in Islam, is not common in Albanians. Apart from some exceptions, monogamy continues to be common among the Albanian families. In fact, there would be no internal marriage among relatives; and marriage is not allowed even if they are from the same tribe. In this way, the traditional marriage culture of Albanians has been preserved. Besides preserving these basic elements of the Albanian family, particularly sexual relations or marriages, Islam has preserved the traditional brotherhood, kinship, and tribal structure, which plays an important role in protecting the ethnic roots of Albanians. Even Albanians who have such a social structure and Albanians who have different religions have lived together in a peaceful way.

The tolerant attitude of the Albanians and Islam has also been a determinant of the unique Albanian identity. The continuation of tolerance, equality and human values is the result of this attitude. There was no religious discrimination among Albanians. The tribes that belonged to the three different religions have always lived in peace.

Some anthropological and sociological studies are needed to sustain the tolerant and rich cultural existence that Albanians have created throughout centuries thanks to Islam. First of all, it is necessary to support the applied sociological and folkloric studies that will reveal the cultural richness among the people with the studies based on authentic historical and anthropological sources at first hand, and this kind of studies should be encouraged.

As a result, Islam has preserved and contributed to strengthen the ethnic existence, language, and original cultural characteristics of the Albanians. This phenomenon includes some of the most important practices and clues that the globalizing world needs for peace and security about multiculturalism.

\section{Referenses}


[1] BASHA, Ali Musa (2000), İslâmi në Shqipëri Gjatë Shekujve, Tiranë: Biblioteka İslâme.

[2] IZZETBEGOVIC, Alija (2015), Islam between East and West, Istanbul: Clasical Publishing.

[3] CEVDET PAŞA, Ahmet (1991), Tezakir-13-20, Release. Cavid Baysun. Ankara: Turkish Historical Society.

[4] DRANÇOLLİ, Fejaz (2004), Rrënimi i Kullës Shqiptare, Prishtinë.

[5] DUKA, Ferit (1983), "Observations on the Process of Islamization of the Albanian Population in the XV-XVIII. Centuries", [Accessed: 12.09.2018]. http://dergiler.ankara.edu.tr.

[6] DURHAM, M.Edith (1909), High Albania, London: Publishers to the India Office.

[7] DURKHEIM Emile (2005), Primitive Forms of Religious Life, Trans. Fuat Aydın, Istanbul: Atac Publications.

[8] ELIOT, T.Stearns (1987), Reflections on Culture, Trans. S. Katarcioglu. Ankara: Ministry of Culture Publications.

[9] EMIN Efendi (1294), Menakıb-1 Kethüdazade El-Hac Mehmed Arif Efendi, Istanbul.

[10] GAWRYCHE, W. George (2006), the Crescent and the Eagle - Ottoman Rule, Islam and the Albanians 1874-1913. London: I.B.Tauris.

[11] GÖKALP, Ziya (2005), Principles of Turkism, Istanbul: Toker Publications.

[12] GÜNAY, Ünver (2014), Sociology of Religion, Istanbul: Human Publications.

[13] HALİMİ-STATOVCİ, Dirita (2009), Veshjet shqiptare të Kosovës, I.A. Prishtinë.

[14] HAMİİ, XH. (2009), Ligjëratë e mbajtur në Universitetin e Vjenës, Prishtinë. [Erişim: 30.09.2016]. www.Telegraf.com.

[15] Kanuni i Lek Dukagjinit (2011), Kuvendi, Shkodwr.

[16] KEMAL BEY, Ismail (1920), the Memoirs of Ismail Kemal Bey, Sommerville Story, London: Constable and Company.

[17] KIEL, Machiel (1990), Ottoman Architekture in Albania (1385-1912), New York: Research Centre for Islamic History.

[18] KRASNIQİ, Mark (1979), Gjurme dhe Gjurmime, Prishtine.

[19] MEMİSHİ, İsa (2011), Roli ulemasë në shkrimin e gjuhës shqipe-studim, Prishtinë: Botoi Jehona Islame.

[20] MORIN, Edgar (1988), Thinking about Europe. Trans. Cute Monopoly, Istanbul:Afa Publications.

[21] LOMONOSOV, Matvey (2013), "On Albanian Identity in the Late Ottoman Empire", pp.8-16. [Access: 27.10.2018]. https://PortaBalkanica_5-2013-15.pdf.

[22] PULAHA, Selami (2011), Kontribut për studimin e ngulitjes së katuneve dhe krijimin e fiseve në Shqipe rine"e veriut shekujt, Prishtine: Instituti Albanologjik.

[23] PİRRAKU, Muhamet (1993), Roli i islamit në integrimin dhe ruajtjen e kombit shqiptar, Hënae re. nr.48-49. Shkup.

[24] RRUGA Ilir (2011), History of Christianity and Islam in Albania, Master Thesis. Konya: Selcuk University Institute of Social Sciences.

[25] RİAJ, Skender (1982), Kosova gjatë shekujve XV, XVI, XVII, Prishtinë: Rilindja.

[26] ROBERT, Elsie (2012), Fjalori Historik i Shqipërisë,Tiranë.

[27] SAYGILI, Hasip (2014), "20. Starting from today Albanians in Ottoman Turkey and perception of the century ", Bilge Strategy. Volume: 6. Issue: 10. (Spring). pp.35-62.

[28] SELIMİ, Yllka (2009), Ndikime islame në disa rite të jetës familjare, Prishtinë: Zëri İslam.

[29] SMITH A. (1999), Myths and Memories of the Nation, Oxford Publishing.

[30] SULEJMANİ and MARTESA, Fadil and Lindja. (1988), Mortja në Malësitë e Tetovës, Prishtinë.

[31] VELIUU, H. İbrahim (2006), Islami nw Balkan arriti para Osmanwve, Kerçovë.

[32] KORAN (2003), the Meaning, Collective. Ankara: Diyanet Foundation Publications.

[33] XHEMAJ, Uke (2005), Shtresime Kulturore, Prishtinë: I.A.P. 